DOI:10.1515/hssr-2016-0001

\title{
Truth and Knowledge
}

Simona Modreanu*

"Alexandru Ioan Cuza" University of Iasi, Romania

True knowledge must be based on and generate Justice thus being a normative knowledge. "Blessed are the lovers of justice ...". The whole universe is structured by means of moral laws. "Heaven and Earth shall pass away, but my words shall not pass away," says Jesus, the fulfiller of the law. This applies to each one of us according to his spiritual level, but there are also some "fixed stars" generally human. Truth, for example, is relative, so justice is done in truth. Maybe the Good is subjective but as divine attribute, it is absolute.

God, in His clemency, latches this knowledge for the people, so that they will not pride with their virtuousity or not despair because of its lack. Essentially, man continues to be a moral being in the world, even though at most times, just potentialy. But one cannot dare to superior knowledge in divinis, if one is not a righteous man. You know all sort of injustice which in vain you will strive to collect in various forms of socalled "coincidence of opposites". Together with morality, our world has also lost its soul. The famous Axis Mundi is righteousand leads to Heaven, while the Anima Mundi is lost in a fog of ethics, in a lack of sense. Some call it absurd, but absurdity exists only in relation to some laws, rules or conveniences.

"I wrote in you all knowledge", says the Lord. What did I do with it? Why are human nature and nature in general imperfect? How much waste and injustice do we need, that can not be understood in any way as

\footnotetext{
"Faculty of Letters, "Alexandru Ioan Cuza" University of Iasi, 11, Carol I Bvd., 700506, Iasi, Romania; simona.modreanu@gmail.com
} 
steps of the spirit towards the perfect self conscience - as Hegel believed. A man and a world created in the image of the Creator can only be a righteous man and a moral world. Unfortunately, morality has been banished from the city, and how many righteous men are left to hold thestrings of the world?

In a simmetric universe, justice happens naturally, continuously. Our social systems have always had a good source of inspiration in this natural order, divine harmony, but failedevery time. This order must only be socially implemented and recognized so that "what is in the sky should be on earth, big and small alike", so that allmay be one, so that man and divinity become one under the veiling music of the spheres, here and now.

Otherwise, individualism, on which modernity's bluff was built, is very operative being based on reason and on a succession of thoughts. It can build lots of systems, which are all false because they are the product of false ego that took our light as a weed does. It is a way of saying, because it could never take the light that we are and it would be better for us to realize this. Nature of the Self is light. I am sorry for my liberal friends but, as Pope John Paul-II said, freedom begins after finding the truth, the rest are forms of libertinism, which they prefer, unfortunately, before attempting to realize who they are. Living in this way, every moment of life becomes an assassin of the Self, an atma-han, as the Hindus say.

Once produced, the realization is eternal. What you seek is not something new, which comes into existence, but is something that exists eternally, is something that we are, but we forgot and we only have to remember. As St. John of the Cross said, "We are here to remember" and truly live, or to accede to pure experience, which is both knowledge and love, to the Life that has been breathed into us and to its inner source. Illumination is generated from within. You are the enlightenment. You are the witness of the three bodies, of the three times, and in addition, you witness the void. It is the one that is missing when you do not count.

The scientific medium needs to borrow more metaphysics as a way of judging, otherwise it risks to become, with its positivism, a "murderer of souls", leading to novel and unpredictable consequences, including its final collapse. Three centuries in which they worked on the statue of 
Descartes, as the modern incarnation of the spirit are sufficient. To find the truth and truly live we need to remove the false representations and deforming concepts and "to dive in the movement of life", as Bergson said.

In turn, W. James, known for his pragmatism, always asked us to go "too far". I do not see anything pragmatic in this or very wise. Haven't our ancients taught us about measure? "Meden Agan" said the Greeks, or "measure of all things". You need to know when and where to stop. And W. James, the son of Swedenbog's disciple, did not know and, in Principles of Psychology (1877) has reestablished psychology on other than the theological principles. It became a sort of statistical and mechanical physiology of the soul. It became the subject of "scientific knowledge". That began to be measured by the meter, until today. From my point of view, W.James was an atmahan a "killer of the soul".

This "revolution" meant for psychic meant the same thing as the French Revolution meant for the history of human civilization. Truth can not be found through such barbarities. It is immutable. Truth and faith are ultimately one. But the truth of an idea can not be determined experimentally, empirically. And an empty lot can express a truth. Similarly, the truth of a soul which through faith can reach and attest to the truth of the Great Soul's Truth, beyond situations, conjectures or events. The Truth of the Self is not relative. We also need the Absolute.

Between the scientific and theological discourse there are three types of relationships - of indifference or separation, of hierarchy, respectively, relations of superiority and inferiority, and dialogue, ranging from the mutual validation and understanding of the other to a state of harmonization and integration. The first type, separation, is not a solution, the second one leads to a standstill, neither of the two discourses accept the subordinate state, and so, we are left with the third way, dialogue: communion, according to which the Big Bang is just another name given to Creation. The ultimate Truth remains a mystery beyond common, rational understanding. But we still need both of them. 
HSS, vol. V, no. 1(2016): 7-10

\section{Biographical note}

Simona Modreanu is a $\mathrm{PhD}$ professor of French and Francophone literature at the Faculty of Letters of the "Alexandru Ioan Cuza" University of Iasi. She is also an essayist and a translator, an active member of the CIRET (Centre International de Recherches et Etudes Transdisciplinaire), Paris and co-director of the Transdisciplinary Studies Center of the University of Iasi. She directed the Romanian Cultural Center in Paris (1991-2001) and the

Junimea Publishing House in Iasi (2008-2014). Main publications : Eugène Ionesco on l'agonie de la signifiance (ed. Axis, Iasi, Roumanie, 2002), Le Dien paradoxal de Cioran (Paris, Ed. du Rocher, 2003), Cioran (Paris, Oxus, 2004),Lecturi nomade (Iasi, Junimea, 2006), Lecturi sedentare (Iasi, Junimea, 2010), Lecturi infidele (Iasi, Junimea, 2014). 